Volume 3 No. 1 Maret 2019

P-ISSN 2550-0805 E-ISSN 2550-0791

http://ejournal.bsi.ac.id/ejurnal/index.php/widyacipta

\title{
Pengaruh Kompensasi Terhadap Kinerja Guru Pada Sekolah Dasar Negeri Jatiwaringin X Bekasi
}

\author{
Kus Daru Widayati \\ Administrasi Bisnis, Fakultas Ekonomi dan Bisnis, Universitas Bina Sarana Informatika \\ Email: kus.kdr@bsi.ac.id
}

Cara Sitasi: Widayati, K. D. (2019). Pengaruh Kompensasi Terhadap Kinerja Guru Pada Sekolah Dasar Negeri Jatiwaringin X Bekasi. Widya Cipta, 3(1), 17-24.

\begin{abstract}
Compensation is one of the important aspect at the company, because it will increase the employees's motivation during their working time. The employee who get compention will feels like their ability was recognised and appreciated by the company, with the result that makes them more hsrd working. The aim of this research was to identify the effect of compentation toward performance of the teachers at the Sekolah Dasar Negeri Jatiwaringin X Bekasi. This research used description quantitative with questioner instrument 30 respondents. The sampling technique that used was saturated sampling. There are several techniques that used on this research, such as coefficient correlation test, coefficient determination test, and regression, all od the datas were analyzed by SPSS version 21. The result showed a positive effect between compentation and teacher's performance. The bound of compentation and teacher's performance got $R=0,493$ as its result, it could be classified as the strong category. While, the effect of compentation toward teacher's performance was $K D=0,493$ equal with 49,3\%, and the regression was $Y=15,697+0,592 x$, the $b$ value was 0,592 which is indicated that the increasing 1 point of work compentation will increase 0,592 point of teacher's performance..
\end{abstract}

Keywords: Compentation, Teacher's performance, Compentation toward performance

\section{PENDAHULUAN}

Sekolah sebagai pengguna jasa guru, dituntut untuk membina dan mengembangkan kualitas penunjang kegiatan belajar yang baik dari para pendidik agar sekolah memiliki hasil sesuai harapan masyarakat. Pembinaan untuk pendidik sangat beraneka ragam, mulai dari mengikutsertakan dalam seminar, sampai memberikan beasiswa kepada guru untuk melanjutkan jenjang pendidikan yang lebih tinggi. Harus diakui para pendidik merupakan faktor utama dalam proses pendidikan. Fasilitas pendidikan yang lengkap dan canggih ditunjang oleh keberadaan guru yang berkualitas maka akan menimbulkan proses belajar mengajar yang baik. Namun, meskipun proses belajar mengajar telah dirumuskan dengan baik, belum tentu hasil yang diperoleh optimal. Hal ini disebabkan banyak hal yang memengaruhi hasil belajar siswa, salah satunya siswa itu sendiri.

Salah satu cara untuk menggerakkan guru agar aktif melaksanakan tugasnya secara profesional adalah dengan memberikan kompensasi atau imbalan jasa, baik berbentuk uang, tunjangan maupun fasilitasfasilitas lainnya sesuai dengan kebijakan yang berlaku. Menurut Simamora dalam (Abdussamad, 2014) Variabel kompensasi memiliki 4 indikator yaitu gaji, insentiftunjangan (kesehatan dan Tunjangan Hari Raya (THR)), dan fasilitas.
Dengan adanya kompensasi ada beberapa tujuan yang ingin dicapai sesuai pendapat dari Notoadmodjo dalam Sutrisno (2017:188) ada beberapa tujuan dari kompensasi yang perlu diperhatikan, yaitu yang pertama adalah menghargai prestasi kerja, dengan pemberian kompensasi yang memadai adalah suatu penghargaan organisasi terhadap prestasi kerja para karyawan. Selanjutnya akan mendorong perilaku-perilaku atau kinerja karyawan sesuai dengan yang diinginkan oleh perusahaan misalnya produktifitas yang tinggi. Selain kompensasi diharapkan dapat menjamin keadilan karena dengan adanya sistem kompensasi yang baik akan menjamin terjadinya keadilan diantara karyawan dalam organisasi. Masing-masing karyawan akan memperoleh kompensasi yang sesuai dengan tugas, fungsi, jabatan dan prestasi kerja. Kompensasi juga dapat mempertahankan karyawan karena dengan sistem kompensasi yang baik, para karyawan akan lebih survival bekerja pada organisasi itu. Hal ini berarti mencegah keluarnya karyawan dari organisasi itu mencari pekerjaan yang lebih menguntungkan. Dengan kompensasi juga dapat memperoleh karyawan yang bermutu karena dengan system kompensasi yang baik akan menarik lebih banyak calon karyawan, akan lebih banyak pula memilih karyawan yang terbaik. Dengan pemberian kompensasi yang memadai, perusahaan 
dapat mengendalikan biaya, karena dengan sistem pemberian kompensasi yang baik, akan mengurangi seringnya melakukan rekrutmen, sebagai akibat semakin seringnya karyawan yang keluar mencari pekerjaan yang lebih menguntungkan di tempat lain. Hal ini berarti penghematan biaya rekrutmen dan seleksi calon karyawan baru. Yang terakhir dengan kompensasi diharapkan dapat memenuhi peraturanperaturan, karena dengan sistem kompensasi yang baik merupakan tuntutan dari pemerintah. Suatu perusahaan yang baik dituntut adanya sistem administrasi kompensasi yang baik pula.

Pemberian kompensasi ini juga merupakan salah satu alat perangsang dalam menumbuhkan semangat dan gairah kerja. Guru yang memiliki semangat mengajar diasumsikan dengan mudah dapat meningkatkan kinerjanya dalam mendidik dan mengajar siswa. Menurut Moheriono dalam (Yuliantari \& Ulfa, 2016), yaitu efektif , efisien, kualitas, ketepatan waktu, produktivitas, dan keselamatan

Namun, banyak opini yang berkembang di masyarakat yang menyatakan bahwa profesi guru sampai saat ini dianggap kurang bergengsi dan kinerjanya di nilai belum optimal, padahal peranan guru sangat penting sebagai bagian dari sistem pendidikan nasional. Hingga saat ini pemerintah memperhatikan persoalan guru dan pendidikan formal karena persoalan guru semakin menjadi persoalan pokok dalam pembangunan pendidikan nasional disebabkan oleh adanya tuntutan perkembangan masyarakat dan perubahan global.

SD Negeri Jatiwaringin $X$ Bekasi adalah badan pemerintahan yang bergerak di bidang pendidikan menerapkan adanya kompensasi terhadap kinerja guru. Kinerja seorang guru dapat dilihat dari cara seorang guru itu dalam menyelesaikan tugasnya. Hasil dari kinerja guru ini adalah prestasi belajar siswa yang baik. Bukan semata-mata nilai yang bagus yang tertera pada raport, tetapi kemampuan siswa itu sendiri atau kemampuannya dalam menerima pelajaran.

\section{A. Kompensasi}

\section{Pengertian Kompensasi}

Kompensasi merupakan salah satu fungsi yang penting dalam manajemen sumber daya manusia. Kasus yang terjadi dalam hubungan kerja mengandung masalah kompensasi dan berbagai segi yang terkait, seperti tunjangan, kenaikan kompensasi, struktur kompensasi, dan skala kompensasi. Sistem kompensasi membantu dalam memberi penguatan terhadap nilai-nilai kunci organisasi serta memfasilitasi pencapaian tujuan organisasi. Kompensasi dimaksudkan sebagai balas jasa (reward) perusahaan terhadap pengorbanan waktu, tenaga, dan pikiran yang telah diberikan karyawan kepada perusahaan (Hamali, 2016:78).

\section{Indikator Kompensasi}

Menurut Simamora dalam (Abdussamad, 2014) Variabel kompensasi memiliki 4 indikator yaitu :

a. Gaji

Imbalan atas jasa yang dinyatakan dalam bentuk uang oleh atasan kepada karyawan atau pegawai, yang dibayarkan sesuai dengan perjanjian kerja, kesepakatan, dan peraturan perundang-undangan.

b. Insentif

Jenis kompensasi yang di luar gaji atau upah yang diberikan oleh organisasi, yang dilihat dari hasil kinerja.

c. Tunjangan (Kesehatan \& Tunjangan hari raya (THR))

Yaitu jenis kompensasi dalam bentuk non financial, seperti asuransi kesehatan dan jiwa, liburan yang ditanggung perusahaan, program pensiun, dan tunjangan lainnya yang berkaitan dengan hubungan kepegawaian.

d. Fasilitas

Jenis kompensasi non financial yang dapat mewakili jumlah substansial dari kompensasi terutama bagi eksekutif yang dibayar mahal oleh perusahaan.

\section{Asas Kompensasi}

Menurut Hasibuan (2017:122) Program kompensasi (balas jasa) harus ditetapkan atas asas adil dan layak serta dengan memperhatikan undang-undang perburuan yang berlaku. Prinsip adil dan layak harus mendapat perhatian dengan sebaik-baiknya supaya balas jasa yang akan diberikan merangsang gairah dan kepuasan kerja karyawan.

a. Asas Adil

Berdasarkan kompensasi yang dibayar kepada setiap karyawan harus disesuaikan dengan prestasi kerja, dan memenuhi persyaratan internal konsistensi.

b. Asas Layak dan Wajar

Kompensasi yang diterima karyawan dapat memenuhi kebutuhan pada tingkat normatif yang ideal. Tolok ukur layak adalah relatif, penetapan besarnya kompensasi didasarkan atas batas upah minimal pemerintah dan eksternal konsistensi yang berlaku.

\section{B. Kinerja}

\section{Pengertian Kinerja}

Kinerja berasal dari pengertian performance. Adapula yang memberikan performance sebagai hasil kerja atau prestasi kerja. Namun, sebenarnya kinerja mempunyai makna yang lebih luas, bukan hanya hasil kerja, tetapi termasuk bagaimana proses pekerjaan berlangsung (Wibowo, 2017:7). 


\section{Indikator Kinerja}

Menurut Moheriono dalam (Yuliantari \& Ulfa, 2016), yaitu:

a. Efektif

Indikator ini mengukur derajat kesesuaian yang dihasilkan dalam mencapai sesuatu yang diinginkan.

b. Efisien

Indikator ini mengukur derajat kesesuaian proses menghasilkan output dengan menggunakan biaya serendah mungkin.

c. Kualitas

Indikator ini mengukur derajat kesesuaian antara kualitas produk atau jasa yang dihasilkan dengan kebutuhan dan harapan konsumen.

d. Ketepatan waktu

Indikator ini mengukur apakah pekerjaan telah diselesaikan secara benar dan tepat waktu.

e. Produktivitas

Indikator ini mengukur tingkat efektivitas suatu organisasi.

f. Keselamatan

Indikator ini mengukur kesehatan organisasi secara keseluruhan serta lingkungan kerja para karyawan ditinjau dari aspek kesehatan.

\section{Faktor-Faktor Yang Memengaruhi Kinerja Pegawai}

Menurut Sedarmayanti dalam Sulaksono (2015:107), faktor-faktor yang memengaruhi kinerja pegawai sebagai berikut :

a. Sikap Mental

Sikap mental yang dimiliki seorang pegawai akan memberikan pengaruh terhadap kinerjanya. Sikap mental yang dapat memengaruhi kinerja pegawai adalah motivasi kerja, disiplin kerja dan etika kerja yang dimiliki seorang pegawai.

b. Pendidikan

Pendidikan yang dimiliki seorang pegawai mempengaruhi kinerja pegawai. Semakin tinggi pendidikan seorang pegawai maka kemungkinan kinerjanya juga semakin tinggi.

c. Keterampilan

Pegawai yang memiliki keterampilan akan mempunyai kinerja yang lebih baik dari pada pegawai yang tidak mempunyai keterampilan.

d. Kepemimpinan

Kepemimpinan manajer memberikan pengaruh terhadap kinerja pegawainya. Manajer yang mempunyai kepemimpinan yang baik akan dapat meningkatkan kinerja bawahannya.

e. Tingkat Penghasilan

Tingkat penghasilan pegawai berpengaruh terhadap kinerja pegawai. Pegawai akan termotivasi untuk meningkatkan kinerjanya apabila mempunyai penghasilan yang sesuai.

f. Kedisiplinan

Kedisiplinan yang kondusif dan nyaman akan dapat meningkatkan kinerja pegawai. g. Komunikasi

Para pegawai dan manajer harus senantiasa menciptakan komunikasi yang harmonis dan baik. Dengan adanya komunikasi yang baik maka akan mempermudah dalam menjalankan tugas instansi.

h. Sarana Pra Sarana

Instansi harus memberikan fasilitas atau sarana dan prasarana yang dapat mendukung kinerja pegawai

i. Kesempatan Berprestasi

Adanya kesempatan berprestasi dalam perusahaan dapat memberikan motivasi kepada pegawai untuk selalu meningkatkan kinerjanya.

Menurut Davis dalam Pramularso (2018), faktorfaktor yang mempengaruhi pencapaian kinerja adalah:

a. Faktor Kemampuan

Secara psikologis, kemampuan (ability) pegawai terdiri dari kemampuan potensi (IQ) diatas ratarata (IQ 110-120) dengan pendidikan yang memadai untuk jabatannya dan terampil dalam menggerakan pekerjaan sehari-hari, maka ia akan lebih mudah mencapai kinerja yang diharapkan. Oleh karena itu pegawai selalu ditempatkan pada pekerjaan yang sesuai dengan keahliannya (the right man in the place, the man on the right job).

b. Faktor Motivasi

Motivasi berbentuk dari sikap (attitude) seorang pegawai dalam menghadapi situasi (situation). Motivasi merupakan kondisi yang menggerakkan diri pegawai yang terarah untuk mencapai tujuan organisasi.

\section{METODOLOGI PENELITIAN}

Metode yang digunakan adalah metode kuantitatif, mengumpulkan data yang diperlukan melalui observasi langsung dan memperhatikan aktivitas pemberian kompensasi terhadap kinerja guru pada Sekolah Dasar Negeri Jatiwaringin X Bekasi, dokumentasi mengacu kepada referensi yang berasal dari buku-buku dan jurnal sebagai landasan teori yang dapat memperkuat keabsahan data.dan kuesioner yang harus dijawab atau dikerjakan oleh responden yaitu guru - guru di Sekolah Dasar Negeri Jatiwaringin X Bekasi untuk mendapatkan informasi langsung tentang masalah yang dibahas pada tugas akhir ini dengan variabel kompensasi $(\mathrm{X})$ terhadap variabel kinerja guru (Y). Dengan menggunakan bantuan aplikasi SPSS.21, dengan periode penyebaran kuesioner pada bulan Mei 2018. Untuk mengukur setiap jawaban responden digunakan skala Likert. Adapun data yang diperoleh akan dianalisis dengan menggunakan uji koefisien kolerasi, uji koefisien determinasi, dan uji persamaan regresi. Sampel yang digunakan dalam penelitian ini adalah sebanyak 30 responden guruguru di Sekolah Dasar Negeri Jatiwaringin X 
Bekasi, yang berisi 10 pernyataan tentang kompensasi (variabel x) dan 10 pernyataan tentang kinerja guru (variabel y).

\section{HASIL DAN PEMBAHASAN}

\section{A. Kisi-kisi Dasar Operasional Variabel}

Kisi-kisi operasional variabel yang penulis gunakan untuk penyusunan daftar pernyataan kuisioner dalam penelitian ini, digambarkan dengan tabel berikut:

\section{Variabel Kompensasi $(\mathrm{X})$}

Tabel 1

Dimensi dan Indikator Variabel Kompensasi (X)

\begin{tabular}{|c|c|c|}
\hline \multicolumn{3}{|c|}{ Kompensasi (X) } \\
\hline Indikator & Dimensi & Butir Pernyataan \\
\hline \multirow[b]{2}{*}{ Gaji } & \multirow{2}{*}{$\begin{array}{l}\text { Imbalan atas jasa } \\
\text { yang dinyatakan } \\
\text { dalam bentuk uang } \\
\text { oleh atasan kepada } \\
\text { karyawan atau } \\
\text { pegawai, yang } \\
\text { dibayarkan sesuai } \\
\text { dengan perjanjian } \\
\text { kerja, kesepakatan, } \\
\text { dan peraturan } \\
\text { perundang- } \\
\text { undangan. }\end{array}$} & $\begin{array}{ll}\text { 1. Gaji } & \text { yang } \\
\text { diterima } & \text { telah } \\
\text { memenuhi } & \\
\text { kebutuhan dasar }\end{array}$ \\
\hline & & $\begin{array}{lr}\text { 2. Gaji } & \text { yang } \\
\text { diterima } & \text { sesuai } \\
\text { dengan } & \text { beban } \\
\text { pekerjaan } & \text { yang } \\
\text { diberikan } & \end{array}$ \\
\hline \multirow{3}{*}{ Insentif } & \multirow{3}{*}{$\begin{array}{lr}\text { Jenis } & \text { kompensasi } \\
\text { yang di luar gaji } \\
\text { atau upah yang } \\
\text { diberikan } & \text { oleh } \\
\text { organisasi, } & \text { yang } \\
\text { dilihat dari } & \text { hasil } \\
\text { kinerja. } & \end{array}$} & $\begin{array}{l}\text { 3. Insentif } \\
\text { memberikan } \\
\text { semangat yang } \\
\text { lebih dalam } \\
\text { bekerja } \\
\end{array}$ \\
\hline & & $\begin{array}{l}\text { 4. Insentif } \\
\text { diberikan untuk } \\
\text { yang berprestasi }\end{array}$ \\
\hline & & 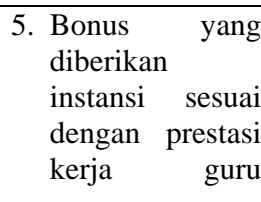 \\
\hline \multirow{2}{*}{$\begin{array}{l}\text { Tunjangan } \\
\text { kesehatan } \\
\text { Tunjangan } \\
\text { hari raya }\end{array}$} & \multirow{2}{*}{$\begin{array}{lr}\text { Yaitu } & \text { jenis } \\
\text { kompensasi dalam } \\
\text { bentuk } \\
\text { financial, seperti } \\
\text { asuransi kesehatan } \\
\text { dan jiwa, liburan } \\
\text { yang ditanggung } \\
\text { perusahaan, } \\
\text { program pensiun, } \\
\text { dan tunjangan } \\
\text { lainnya yang } \\
\text { berkaitan dengan } \\
\text { hubungan } \\
\text { kepegawaian. }\end{array}$} & $\begin{array}{l}\text { 6. Sekolah } \\
\text { memberikan } \\
\text { tunjangan cuti } \\
\text { hamil untuk } \\
\text { pegawainya }\end{array}$ \\
\hline & & $\begin{array}{l}\text { 7. Sekolah } \\
\text { memberikan } \\
\text { jaminan } \\
\text { kesehatan untuk } \\
\text { guru dan para } \\
\text { pegawainya }\end{array}$ \\
\hline
\end{tabular}

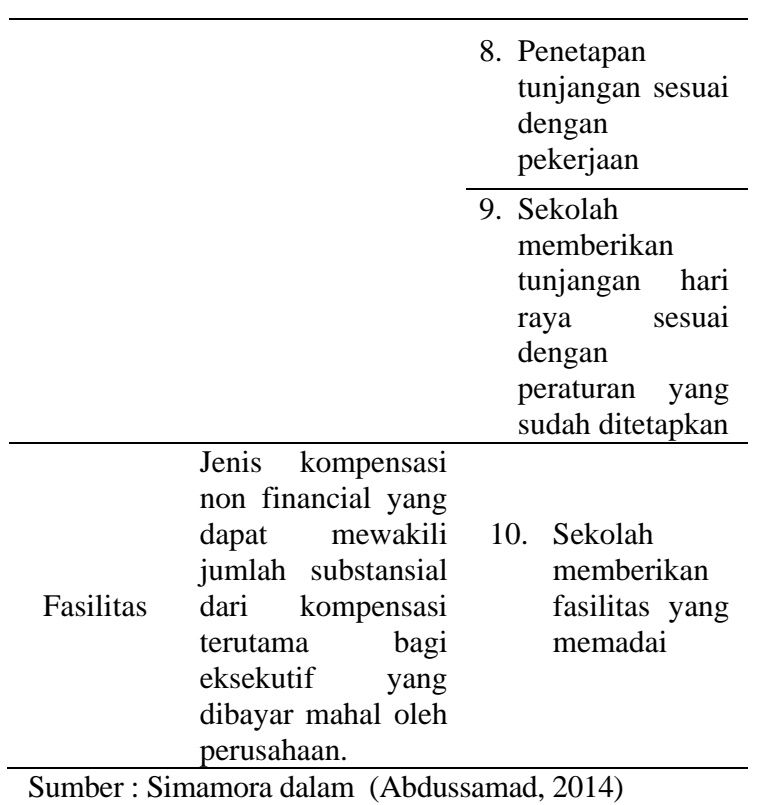

\section{Variabel Kinerja Pegawai (Y)}

Tabel 2

Dimensi dan Indikator Variabel Kinerja Guru (Y)

\begin{tabular}{|c|c|c|}
\hline \multicolumn{3}{|c|}{ Kinerja Guru (Y) } \\
\hline Indikator & Dimensi & Butir Pernyataan \\
\hline Efektif & $\begin{array}{l}\text { 1. Hasil } \\
\text { kinerja } \\
\text { karyawan }\end{array}$ & $\begin{array}{l}\text { 1.Mampu bekerja } \\
\text { sesuai dengan } \\
\text { ketentuan yang } \\
\text { berlaku }\end{array}$ \\
\hline Efisien & $\begin{array}{l}\text { 2. Pekerjaan } \\
\text { sesuai } \\
\text { dengan } \\
\text { target }\end{array}$ & $\begin{array}{lr}\text { 2.Mampu } & \\
\text { menggunakan } \\
\text { waktu dengan } \\
\text { efisien resuai } \\
\text { dengan yang } \\
\text { sudah r } \\
\text { ditetapkan oleh } \\
\text { instansi }\end{array}$ \\
\hline \multirow{2}{*}{ Kualitas } & $\begin{array}{l}\text { 3. Hasil kerja } \\
\text { karyawan }\end{array}$ & \begin{tabular}{lr}
\multicolumn{3}{l}{ 3. Kemampuan } \\
yang & saya \\
miliki & sesuai \\
dengan & \\
pekerjaan & yang \\
diberikan &
\end{tabular} \\
\hline & $\begin{array}{l}\text { 4. Kualitas } \\
\text { produk atau } \\
\text { jasa sama } \\
\text { dengan } \\
\text { harapan } \\
\text { konsumen }\end{array}$ & $\begin{array}{l}\text { 4.Dalam } \\
\text { mengajar sesuai } \\
\text { dengan harapan } \\
\text { orang tua murid }\end{array}$ \\
\hline $\begin{array}{l}\text { Ketepatan } \\
\text { waktu }\end{array}$ & $\begin{array}{l}\text { 5. Mengukur } \\
\text { kinerja } \\
\text { karyawan } \\
\text { telah } \\
\text { selesai } \\
\text { secara } \\
\text { benar dan } \\
\text { tepat waktu }\end{array}$ & $\begin{array}{l}\text { 5.Dapat } \\
\text { menyelesaian } \\
\text { pekerjaan } \\
\text { sesuai dengan } \\
\text { waktu yang } \\
\text { sudah } \\
\text { ditentukan } \\
\text { sekolah }\end{array}$ \\
\hline
\end{tabular}




\begin{tabular}{|c|c|c|}
\hline \multirow{3}{*}{ Produktivitas } & $\begin{array}{l}\text { 6. Para } \\
\text { karyawan } \\
\text { bekerja } \\
\text { dengan } \\
\text { benar }\end{array}$ & $\begin{array}{lr}\text { 6. Bekerja } & \text { dengan } \\
\text { benar } & \text { sesuai } \\
\text { dengan SOP } & \text { SOang sudah } \\
\text { yang } & \text { ditentukan } \\
\text { sekolah } & \end{array}$ \\
\hline & $\begin{array}{l}\text { 7. Inisiatif } \\
\text { karyawan }\end{array}$ & $\begin{array}{l}\text { 7. Dapat } \\
\text { menyelesaikan } \\
\text { masalah dengan } \\
\text { orangtua anak } \\
\text { didik } \\
\end{array}$ \\
\hline & $\begin{array}{l}\text { 8. Kerjasama } \\
\text { karyawan }\end{array}$ & $\begin{array}{l}\text { 8. Dapat bekerja } \\
\text { sama sesama } \\
\text { guru, staf, dan } \\
\text { orangtua }\end{array}$ \\
\hline \multirow{2}{*}{ Keselamatan } & 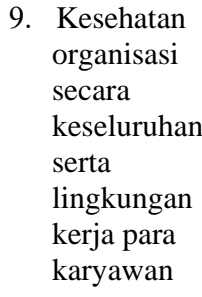 & $\begin{array}{l}\text { 9. Lingkungan } \\
\text { sekolah yang } \\
\text { bersih akan } \\
\text { berpengaruh } \\
\text { pada kesehatan } \\
\text { guru }\end{array}$ \\
\hline & $\begin{array}{l}\text { 10. Asuransi } \\
\text { karyawan }\end{array}$ & $\begin{array}{l}\text { 10. Kesehatan } \\
\text { guru sudah } \\
\text { dijamin } \\
\text { dengan } \\
\text { menggunakan } \\
\text { asuransi }\end{array}$ \\
\hline
\end{tabular}

Sumber : Abdullah dalam (Yuliantari \& Ulfa, 2016)

\section{B. Uji Instrumen}

Pengujian instrumen dilakukan untuk memastikan bahwa data yang digunakan dapat dipercaya. Uji instrumen terdiri dari Uji Validitas dan Realibilitas.

\section{Validitas}

Menurut Sugiyono dalam (Pramularso, 2018), menyatakan bahwa "dalam perhitungan validitas menggunakan teknik korelasi person product moment dengan program SPSS. Biasanya syarat minimum untuk dianggap memenuhi syarat adalah kalau $\mathrm{r}=0,3$. Jadi kalau relasi antar butir dengan skor total kurang dari 0,3 maka butir dalam instrumen dinyatakan tidak valid".

\section{Uji Realibilitas}

Reliabilitas merupakan suatu indikator atau kuesioner dari perhitungan menggunakan SPSS dapat dilihat dari nilai Cronbach's Alpha, kemudian diintrepretasikan pada tabel skala Cronbach's Alpha. Menurut Noor dalam (Pramularso, 2018), menyatakan bahwa "perhitungan untuk reliabilitas menggunakan rumus Alpha Chronbach juga dengan program SPSS. Jika nilai Alpha $>0,60$, disebut reliabel". Pengujian dilakukan dengan membandingkan $r$ hitung dengan $r$ tabel. Nilai $r$ hitung merupakan hasil korelasi jawaban responden pada masing-masing pernyataan di setiap variabel yang dianalisa oleh penulis dengan program SPSS 21. Metode yang sering digunakan terhadap validitas kuesioner adalah korelasi antara skor tiap butir pernyataan dengan skor total, sehingga sering disebut dengan item-item total correlation. Besarnya $\mathrm{r}$ tabel degan taraf signifikan 5\% maka df $=(30-2) 5 \%$ maka besar $r$ tabel ialah (28) 5\% yaitu 0,3610. Hasil validitas program SPSS menunjukan nilai $r$ hitung indikator lebih besar dari $\mathrm{r}$ tabel, artinya semua indikator adalah alat ukur yang dapat dipercaya untuk mendapatkan data valid.

Hasil Reliabilitas output SPSS dapat dilihat sebagai berikut.

Tabel 3. Hasil Reliabilitas

\begin{tabular}{lcl}
\hline \multicolumn{1}{c}{ Variabel } & $\begin{array}{l}\text { Cronbach's } \\
\text { alpha }\end{array}$ & Keterangan \\
\hline Gaya Kepemimpinan & 0,845 & $\begin{array}{l}\text { Sangat } \\
\text { Reliabel }\end{array}$ \\
\hline Kinerja Guru & 0,854 & $\begin{array}{l}\text { Sangat } \\
\text { Reliabel }\end{array}$ \\
\hline Sumber : Data primer yang diolah penulis SPSS 21 (2018)
\end{tabular}

Dari tabel diatas menunjukan nilai cronbach's alpha semua variabel masuk ke dalam kategori sangat reliabel, sehingga dapat disimpulkan indikator atau kuesioner yang digunakan dalam penelitian ini adalah handal dan dapat dipercaya sebagai alat ukur variabel.

\section{Analisis Variabel Kompensasi Terhadap Kinerja Guru}

\section{Uji Koefisien Korelasi}

Koefisien korelasi digunakan untuk mengukur kuat hubungan antara variabel bebas dengan variabel terikat.

Ho : Tidak adanya pengaruh kompensasi dengan kinerja guru pada Sekolah Dasar Negeri Jatiwaringin X Bekasi.

$\mathrm{Ha}$ : Ada pengaruh kompensasi terhadap kinerja guru pada Sekolah Dasar Negeri Jatiwaringin $\mathrm{X}$ Bekasi.

Setelah diketahui butir-butir dalam instrumen valid dan dapat dipercaya, maka selanjutnya adalah mencari arah kuatnya hubungan antara kompensasi dengan kinerja guru menggunakan rumus korelasi. Melalui bantuan SPPS.21 maka hasil hubungan antara kompensasi terhadap kinerja guru dapat dilihat sebagai berikut : 
Tabel 4

Hasil Koefisien Korelasi

\begin{tabular}{|c|c|c|c|}
\hline \multicolumn{4}{|l|}{ Correlations } \\
\hline & & kompensasi & Kinerja \\
\hline \multirow{4}{*}{ Kompensasi } & Pearson & 1 &, $702^{* * *}$ \\
\hline & Correlation & & \\
\hline & Sig. (2-tailed) & & ,000 \\
\hline & $\mathrm{N}$ & 30 & 30 \\
\hline \multirow{3}{*}{ Kinerja } & $\begin{array}{l}\text { Pearson } \\
\text { Correlation }\end{array}$ &, $702^{* *}$ & 1 \\
\hline & Sig. (2-tailed) & 000 & \\
\hline & $\mathrm{N}$ & 30 & 30 \\
\hline
\end{tabular}

**. Correlation is significant at the 0.01 level (2-tailed).

Sumber : Hasil Data Output SPSS.21

Dari tabel 4 maka dapat disimpulkan bahwa nilai korelasi (hubungan) antara kompensasi dengan kinerja guru sebesar 0,702. Berdasarkan tabel pedoman interprestasi koefisien korelasi, nilai tersebut termasuk dalam kategori kuat. Sehingga bisa disimpulkan bahwa hubungan positif sebesar 0,702 antara kompensasi terhadap kinerja guru.

\section{Uji koefisien Determinasi}

Koefisien determinasi digunakan untuk menghitung besar kecilnya pengaruh variabel $\mathrm{X}$ terhadap $\mathrm{Y}$.

Ho : Tidak ada pengaruh kompensasi dengan kinerja guru pada SD Negeri Jatiwaringin X Bekasi.

Ha : Ada pengaruh kompensasi terhadap kinerja guru pada SD Negeri Jatiwaringin X Bekasi.

Selanjutnya adalah mencari koefisien determinasi. Koefisien determinasi digunakan untuk mengetahui seberapa besar kemampuan variabel independen (Kompensasi) menjelaskan variabel dependennya (Kinerja guru) yang dilihat melalui $\mathrm{r}$ Square dari perhitungan melalui SPSS. Berikut adalah tabel hasil pengolahannya :

Tabel 5

Hasil Koefisien Determinasi Model Summary

\begin{tabular}{|c|c|c|c|c|}
\hline \multicolumn{5}{|c|}{ Model Summary } \\
\hline Model & $\mathrm{R}$ & R Square & $\begin{array}{c}\text { Adjusted R } \\
\text { Square }\end{array}$ & $\begin{array}{l}\text { Std. Error of } \\
\text { the Estimate }\end{array}$ \\
\hline 1 &, $702^{\mathrm{a}}$ & ,493 &, 475 & 2,129 \\
\hline
\end{tabular}

Sumber : Hasil Data Output SPSS.21

Dari hasil tabel 5 menunjukan koefisien determinasi yang diseusaikan (R Square) adalah sebesar 0,493 artinya 49,3\% variabel kompensasi dapat dipengaruhi oleh variabel kinerja guru sedangkan sisanya sebesar $50,7 \%$ dijelaskan oleh faktor lain. Hal ini berarti disarankan bagi peneliti berikutnya yang berminat melakukan penelitian kinerja guru untuk meneliti dari aspek lain seperti motivasi, disiplin kerja dan lain sebagainya karena masih ada sebesar 50,7\% aspek lain yang belum dimasukkan dalam penelitian ini.
Tabel 6

Tabel Anova

\begin{tabular}{|c|c|c|c|c|c|c|}
\hline \multicolumn{7}{|c|}{ ANOVA $^{a}$} \\
\hline Model & & $\begin{array}{l}\text { Sum of } \\
\text { Squares }\end{array}$ & Df & $\begin{array}{c}\text { Mean } \\
\text { Square }\end{array}$ & $\mathrm{F}$ & Sig. \\
\hline \multirow{3}{*}{1} & $\begin{array}{l}\text { Regressio } \\
n\end{array}$ & 123,332 & 1 & 123,332 & 27,198 &, $000^{\mathrm{b}}$ \\
\hline & Residual & 126,968 & 28 & 4,535 & & \\
\hline & Total & 250,300 & 29 & & & \\
\hline
\end{tabular}

a. Dependent Variable: kinerja

b. Predictors: (Constant), kompensasi

Sumber : Hasil Data Output SPSS.

Berdasarkan tabel 6 anova dapat diketahui bahwa nilai signifikan $0,000<0,05$ maka keputusan $\mathrm{Ha}$ diterima, dapat disimpulkan bahwa ada pengaruh yang signifikan antara kompensasi terhadap kinerja guru.

\section{Uji Persamaan Regresi}

Regresi sederhana digunakan untuk melakukan prediksi seberapa tinggi nilai variabel dependen bila nilai variabel independen dimanipulasi (dirubahrubah) berdasarkan hasil analisis menggunakan SPSS, maka diperoleh hasil regresi antara kompensasi terhadap kinerja guru sebagai berikut :

Ho : Tidak ada pengaruh kompensasi dengan kinerja guru pada SD Negeri Jatiwaringin X Bekasi.

Ha : Ada pengaruh kompensasi terhadap kinerja guru pada SD Negeri Jatiwaringin X Bekasi.

Tabel 7

Hasil Analisis Regresi Kompensasi Terhadap Kinerja

\begin{tabular}{|c|c|c|c|c|}
\hline \multicolumn{5}{|c|}{ Coefficients ${ }^{\mathrm{a}}$} \\
\hline \multirow[t]{2}{*}{ Model } & $\begin{array}{r}\text { Unstar } \\
\text { Coef }\end{array}$ & $\begin{array}{l}\text { Irdized } \\
\text { ients }\end{array}$ & $\begin{array}{l}\text { Standardized } \\
\text { Coefficients }\end{array}$ & Sig. \\
\hline & $\mathrm{B}$ & $\begin{array}{c}\text { Std. } \\
\text { Error }\end{array}$ & Beta & \\
\hline (Constant) & 15,697 & 4,734 & & 3,316 \\
\hline Kompensasi &, 592 &, 114 & ,702 & 5,215 \\
\hline
\end{tabular}

a. Dependent Variable: kinerja

Sumber : Hasil Data Output SPSS.21

Berdasarkan tabel perhitungan SPSS di atas, dapat diperoleh persamaan yaitu : $Y=15,697+0,592 X$. Dari persamaan fungsi di atas, dapat di interprestasikan bahwa bila kompensasi bersifat konstan atau bernilai 0 (nol) maka Y (Kinerja Karyawan) sebesar 15,697. Koefisien regresi sebesar 0,592 menyatakan bahwa setiap penambahan (karena tanda positif) 1 kali untuk kompensasi akan meningkatkan kinerja guru sebesar 0,592. Jadi arah hubungan kompensasi terhadap kinerja guru adalah positif yang searah.

Dari hasil penelitian yang sudah dilakukan terhadap guru-guru di Sekolah Dasar Negeri Jatiwaringin X Bekasi, nilai skor pembobotan terendah dari variabel 
kompensasi adalah dimensi tunjangan kesehatan dengan bobot 103, hal ini menunjukkan masalah tunjangan terhadap para guru masih belum dijalankan secara optimal, seperti tidak semua guru mendapatkan tunjangan kesehatan, hanya dosen yang sudah tetap saja yang mendapatkan tunjangan tetapi yang belum tetap atau yang masih honorer belum mendapatkan tunjangan kesehatan. Padahal guru honorer juga sudah bekerja dan ikut andil dalam memajukan sekolah dan mereka pun juga membutuhkan tunjangan kesehatan yang sama. Saran dari penulis dalam dimensi ini adalah sekolah agar memberikan jaminan kesehatan tidak hanya pada pegawai tetap, tetapi juga pada pegawai honorer.

Demikian juga dalam nilai skor pembobotan terendah dari variabel kinerja adalah dimensi keselamatan dengan bobot 91. Artinya karena sekolah belum bisa menjamin kesehatan para pegawai dan guru dengan menggunakan asuransi, maka kinerja dari segi keselamatan kerja dianggap kurang mencukupi. Dengan demikian, untuk meningkatkan kinerja dalam hal jaminan kesehatan bagi para guru di SD Negeri Jatiwaringin X Bekasi, maka diharapkan pihak sekolah agar dapat meringankan beban biaya pengobatan para pegawai / guru yang memerlukan khususnya pagi guru honorer.

Adanya pengaruh antara kompensasi dengan kinerja guru, diharapkan pihak sekolah maupun dinas pendidikan lebih fokus dalam menyikapi masalah kompensasi secara adil terhadap guru tetap maupun guru yang masih honorer, karena faktor ini sangat menentukan kinerja guru. Namun, di lain pihak setiap setiap guru harus dapat meningkatkan kinerja dalam melakukan pekerjaan sesuai dengan peraturan yang sudah ditetapkan oleh sekolah, dengan meningkatkan kedisiplinan yang kondusif karena pemberian kompensasi dari sekolah kepada para guru tidak malah menjadikan para guru terlena dengan yang sudah diberikan, sehingga apabila guru melanggar peraturan yang ada di dalam sekolah, maka pihak sekolah tetap harus bertindak tegas dengan memberikan sanksi sesuai dengan tingkat kesalahan yang dilakukan oleh guru. Agar tidak terjadi salah pengertian antara para guru dan pihak sekolah, maka kedua belah pihak harus senantiasa menciptakan komunikasi yang harmonis dan baik. Dengan adanya komunikasi yang baik maka akan mempermudah dalam menjalankan tugas di sekolah.

\section{KESIMPULAN}

Dari seluruh hasil perhitungan yang penulisan lakukan, tentang pengaruh kompensasi terhadap kinerja guru pada SD Negeri Jatiwaringin X Bekasi, sebagai berikut:

1. Berdasarkan hasil uji Koefisien Korelasi terdapat nilai signifikan sebesar 0,000 . Apabila nilai signifikan $<0,05$ maka terdapat hubungan antara kompensasi terhadap kinerja guru. Dan dapat diketahui besar hubungan kompensasi terhadap kinerja guru dilihat dari Pearson Correlation sebesar 0, 702. Bahwa terdapat hubungan kuat antara variabel kompensasi terhadap variabel kinerja guru SD Negeri Jatiwaringin X Bekasi.

2. Dari perhitungan Koefisien Determinasi (KD) sebesar 0,493 artinya 49,3\% variabel kompensasi dapat dipengaruhi oleh variabel kinerja guru sedangkan sisanya sebesar $50,7 \%$ dijelaskan oleh faktor lainya.

3. Berdasarkan hasil uji persamaan regresi bahwa terdapat nilai signifikan sebesar $0,000<0,5$ sehingga $\mathrm{H}_{\mathrm{a}}$ diterima yaitu persamaan regresi signifikan. Didapatkan persamaan $\mathrm{Y}=15,697+$ $0,592(\mathrm{X})$, yang artinya apabila nilai $\mathrm{X}$ untuk kompensasi bertambah satu maka akan meningkatkan nilai $\mathrm{Y}$ untuk kinerja, jadi arah hubungan kompensasi terhadap kinerja guru adalah positif yang searah.

\section{REFERENSI}

Abdussamad, Z. (2014). pengaruh kompensasi terhadap produktivitas kerja karyawan pada PT asuransi jiwasraya gorontalo. Manajemen, XVIII, 456-466. Retrieved from https://scholar.google.co.id/scholar?start=10 \&q=Jurnal+tentang+Indikator+kompensasi \& hl=en\&as_sdt=0,5\&as_vis $=1 \# d=g s \_q a b s \& p=$

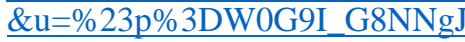

Hamali, A. Y. (2016). Pemahaman Manajemen Sumber Daya Manusia (Strategi Mengelola Karyawan) (Pertama). Yogyakarta: CAPS (Center for Academic Publishing Service).

Hasibuan. (2017). Manajemen Sumber Daya Manusia. Jakarta:Bumi Akasara.

Pramularso, E. Y. (2018). Pengaruh Kompetensi terhadap Kinerja Karyawan CV Inaura Anugerah Jakarta. Widya Cipta - Jurnal Sekretari Dan Manajemen, 2(1), 40-46. Retrieved from http://ejournal.bsi.ac.id/ejurnal/index.php/wid yacipta/article/view/2803

Sugiyono. (2015). Metode Penelitian Kuantitatif Kualitatif dan $R \& D$. Bandung:Alfabeta.

Sulaksono. (2015). Budaya Organisasi dan Kinerja. Bekasi:Cv Bagus Utama.

Sutrisno. (2017). Manajemen Sumber Daya Manusia. Jakarta: Kencana.

Wibowo. (2017). Manajemen Kinerja. Jakarta:Raja Grafindo Persada. 
Yuliantari, K., \& Ulfa, S. N. (2016). Disiplin Kerja Mempengaruhi Kinerja Karyawan Pada PT. Megah Bangun Baja Semesta Jakarta. Jurnal Administrasi Kantor Bina Insani, 4(2), 354373. Retrieved from http://ejournalbinainsani.ac.id/index.php/JAKBI/article/vie $\mathrm{w} / 185$

\section{PROFIL PENULIS}

Dra. Kus Daru Widayati, MM adalah dosen di Administrasi Bisnis, Fakultas Ekonomi dan Bisnis, Universitas Bina Sarana Informatika. Pendidikan Sarjana 1 di Antropologi Universitas Gajah Mada, dan melanjutkan ke Pasca Sarjana Magister Management Universitas Bina Sarana Informatika. Dan sekarang masih aktif mengajar di fakultas Ekonomi dan Bisnis, Universitas Bina Sarana Informatika dan mengajar juga di Fakultas Ekonomi, Universitas Trisakti. 